\title{
IMPROVING PERFORMANCE OF BISCUIT PRODUCTION PROCESS THROUGH LEAN SIX-SIGMA AT PT XYZ
}

\author{
Ahmad Mukti Almansur ${ }^{*}$,, Sukardi ${ }^{* *)}$, and Machfud ${ }^{* *}$ \\ *) PT Kraft Ultrajaya Indonesia \\ Raya Cimareme Road, No. 131, Padalarang, Bandung, 40552 \\ **) Department of Agroindustrial Technology, Faculty of Agricultural Technology, Bogor Agricultural University \\ Fateta Building, $2^{\text {nd }}$ Floor, IPB Darmaga Campus, Bogor 16680
}

\begin{abstract}
This research aims to analyze waste or loss using the 7-waste approach and value added/non value added activities in the production process at PT. XYZ. This research also aims to evaluate the production process capability and sigma values at PT. XYZ and used DMAIC technique (Define, Measure, Analysis, Improvement, and Control) from Lean Six-sigma with an analysis using Failure Mode and Effect Analysis (FMEA). The results of the research obtained the values of Process Cycle Efficiency (PCE) of 47.29\%, CTQ (Critical to Quality) and process capability value in the form of Cpm (Capability Index) for each process stage and yield. Line-5 has DPMO (Defects per Million Opportunities) value of 29,632,607 with a Sigma Score 3.39, and FMEA (Failure Mode and Effect Analysis) analysis resulted in recommendations for improvement at each process stage.
\end{abstract}

Keywords: process cycle efficiency, biscuit, lean six-sigma, CTQ, Cpm

\begin{abstract}
ABSTRAK
Penelitian ini bertujuan melakukan analisis tingkat pemborosan (waste/loss) dengan menggunakan pendekatan 7 waste dan value added/non value added activity dalam proses produksi di PT. XYZ. Selanjutnya, melakukan evaluasi terhadap nilai kapabilitas proses produksi dan nilai sigma di PT. XYZ. Penelitian ini menggunakan teknik DMAIC (Define, Measure, Analysis, Improvement, and Control) dari Lean Six Sigma dengan Analisis menggunakan menggunakan alat Failure Mode and Effect Analysis (FMEA). Hasil Penelitian mendapati nilai Process Cycle Efficiency (PCE) 47.29\%, CTQ (Critical to Quality) dan nilai kapabilitas proses berupa Cpm (Capability Index) setiap tahapan proses dan Yield. Line-5 memiliki DPMO (Defects Per Million Opportunities) sebesar 29632.607 dengan Sigma Score 3.39 Sigma, analisis FMEA(Failure Mode and Effect Analysis) menghasilkan rekomendasi perbaikan di setiap tahapan proses.
\end{abstract}

Kata kunci: process cycle efficiency, biskuit, lean six sigma, CTQ, Cpm

\footnotetext{
${ }^{1}$ Corresponding author:

Email: ciconsultan@gmail.com
}

\section{INTRODUCTION}

As one of the most populous countries in the world, Indonesia has great potentials in the fast moving consumer goods industries (Fast Moving Consumer Goods/FMCG). Nevertheless, year 2015 became a year full of challenges for business actors in the country. This is characterized by a number of major retailers in Indonesia that lost their sales volume growth because the inflation rate reached $8-11 \%$. Some retailers had nearly zero growth or nadir point growth in their sales volume in Fast Moving Consumer Goods industries (FMCG) nationally; moreover, a number of traditional outlets actually had minus growth. In reference to the data from the Indonesian Retail Entrepreneur
Association (APRINDO), in the first quarter (Q1) of 2014 , the retailer sales volume was still at $15.4 \%$; however, in the fourth quarter (Q4) of 2014, the figure fell to $6.2 \%$, and it continued to fall in March 2015, reaching the lowest point of $2.6 \%$.

Based on the data from the Association of Indonesian Retail Entrepreneurs (APRINDO) (2014) "Business downfall or business downturn has occurred" If in the future the company's performance continues to deteriorate, most companies are forced to cut their Human Resources (HR) $(\mathrm{PHK}=$ Termination of Employment). Therefore, one of the solutions selected by FMCG companies is to conduct cost efficiency policy in order to have better competitiveness. In this 
case, the problem of the industrial processes in the increasingly competitive domestic and international markets is the need to produce high quality products with less energy and resources. The rapidly changing market demands require great differences in value and demand, thus, resulting in the process conditions to be performed. Performance of a company should be maximized to achieve a high level of productivity.

FMCG industries including food industry are industries with a fairly tight competitiveness. Each manufacturer competes in terms of achieving quality, cheap product, low production cost, and resource maximization. Food industry is one of the agriculturebased industries, because essentially the produced foods are part of the agricultural products, and they are then given added values as agricultural products. Therefore, food industry plays an important role in the Indonesian economy. Companies engaged in the food industry is a manufacturing-based company whose operational management plays an important role in achieving company goals, especially related to cost and quality. In addition to the operational management, the achievement of corporate goals is also closely related to the management of strategies that will provide guidance for companies to move effectively.

Womack et al. (1996) defines waste as every human activity that uses resources but does not create added values. Such activities occur like errors that require repair, and excessive production results in storage (inventory), and movements of products or workers that are not needed and so forth.

A number of previous researches used as benchmarks by the authors included: Asmah (2011), studying the design of biscuit production in Ghana Africa states that biscuit production process includes raw material preparation process, mixing, molding, baking or oven, cooling and packing. Each process has a certain design and layout in order to obtain quality, and good process capability and capacity are obtained in order to meet the needs of consumers. Furthermore, the research by Harry and Schroeder (2000), explains that the process of improving the production process is performed by measuring the six-sigma values by using Rolled Throughput Yield (rt) that is by measuring the entire chain of production adjusted to quality parameters, efficiency and conformity to standards, the values of this Y rt and DPU (Defect per Unit) as well as overall sigma were measured.
Ammar Research (2011) says supply chain performance is highly dependent on consistent quality and timely delivery. A defective product or late service will not give satisfaction to customers. Quality is generally defined as a measure of customer satisfaction, but different definitions were used because, in the supply chain, timely delivery context also plays an important role in achieving the desired level of customer satisfaction. There are various performance measures or conventional matrixes which can be used to monitor production in a manufacturing company, one of which is Rolled Throughput Yield (Yrt) Six-sigma. On the other hand, Kumar and Kaushish (2015) conducted a research on the decrease of scrap in piston production using DMAIC method, determination of CTQ from consumer, and improvements are made according to the process stages by developing counter measure in every process variation, critical stage and giving priority for improvement, such conducting training for caster section, conducting decomposition in the process, and heating rings in the oven. From these activities, the results in which there was a decrease of Scrap from 99.000 to 50.000 DPMO and an increase of the sigma value from 2.86 to 3.2 were obtained. In contrast, Zaqi and Suseno (2014) conducted a research on product quality improvement using Lean Sigma and Kaizen methods to measure the sigma performance level of PT. "X" during the production processes of 2012 with an average 4.65 of sigma or DPMO value of 879.67. The highest number of defect type during the production of 2012 was the total reject. The key quality characteristic of the total reject which was the highest in the production process was the porous poles with a depth of $>25 \mathrm{~mm}$. Reviews on some previous studies have supported the use of Lean Six-sigma method with DMAIC and the use of RTY method in determining the six-sigma value appropriate to answer the problems and research objectives.

This research aims to analyze waste/loss by using the 7-waste approach and value added/non-value added activities in the production process at PT. XYZ. In addition, it also aims to evaluate the values of production process capability and sigma at PT. XYZ.

This research was limited to Line 5 production process at PT XYZ, focusing on waste/loss identification in Line 5. Following this, DMAIC implementation was processed in Lean Six-sigma method to determine the process capability level and sigma value, and recommendations on improvement actions through FMEA (Failure 
Mode and Effect Analysis) procedures were given to determine the priority level of improvement actions to be performed.

\section{METHODS}

This research was conducted at PT. XYZ, located at Jababeka Raya Street, Jababeka Industrial Estate Cikarang, Bekasi from June 2015 to August 2015. The method used in this research was case study method using primary and secondary data collected from PT. $\mathrm{XYZ}$. The primary data were obtained from every activity in the production shift during the period of March - June 2015, and the secondary data were obtained from production reports and other supporting data of PT. XYZ. These data were also obtained from direct observations in the study sites and some data sources were obtained through discussions and interviews with the company. Data processing was conducted using Minitab Program Version 17 and Microsoft Excel.

This study used DMAIC (Define, Measure, Analysis, Improvement, and Control) technique from Lean Sixsigma, which began with the Define stage (Pyzdek, 2003) to identify the observed objects. The results of this identification were illustrated by a value stream mapping diagram, to determine the actual condition of the observed objects in several indicators, including value added and non value added time. The value of Process Cycle Efficiency (PCE) was calculated to determine the value of Lean application level at PT. $\mathrm{XYZ}$. This was then followed by measuring stage in which the process of measuring and identification of waste occurring at every stage of production process was conducted. The occurrence of each waste was measured and classified using the approach of 7-waste classification and finally calculated by Pareto analysis. Furthermore, the determination of Critical to Quality (CTQ) value at each stage of the process was determined, and the value of process capability for each stage of the process was measured. The values of $\mathrm{Cpm}$ of each stage of the process, DPMO and sigma of each stage of production process were determined using Rolled Throughput Yield (Yrt) and Cpm value. According to Ammar (2011), C pm is a measurement of the value of process capability used to measure the capacity of a process stage toward the existing standards. The research was continued with the analysis stage i.e. analyzing the causes of the occurrence of waste. The analysis was performed using the Failure Mode and Effect Analysis
(FMEA) tool. According to Stamatis (1995), FMEA is a methodology used to evaluate failures occurring in a system, design, process, or service. Identification of potential failures is performed by scoring each mode of failure based on the occurrence, severity, and detection levels.

According to Gazpersz (2010), improvements in the efficiency of production processes within the company can be conducted by applying several methods, and one of which that has been recognizably successful is Lean Six-sigma. The Lean concept is the streamlining or efficiency of a process, whereas Six-sigma is defined as a process that produces no more than 3.4 defective products per million opportunities (3.4 defects per million opportunities). Efforts in achieving this were conducted in 5 phases called DMAIC (Define, Measure, Analyze, Improve, and Control). Six-Sigma uses metric values to compute any kind of process for a success in an organization so that the current process performance and result of changes made can be measured. The purpose of implementing Lean Six-sigma is not solely to achieve the Six-sigma quality level, but rather to increase the profitability of the company by improving its product quality and by achieving efficiency. According to Furterer (2011), Lean Six-sigma is an approach focusing on improving quality, reducing variation and eliminating waste within an organization, and this is a combination of two improvement programs i.e. Six-sigma and Lean Enterprise.

According to Pyzdex (2003), Lean-Six-sigma is a combination of Lean and Six-sigma and can be defined as a business philosophy. Arunagiri and Babu (2013) in the International Journal of Science and Research says that Lean Six-sigma is a systematic approach to identify and eliminate the 7 types of wastes or nonvalue-added activities through radical continuous improvements to achieve six-sigma performance levels i.e. by flowing products (materials, work-in-processes, outputs) and information using pull systems from the internal and external customers to pursue excellence and perfectness in which the company only produces 3.4 defects for every million opportunity or operations - 3.4 DPMO (Defects per Million Opportunities).

By using FMEA, the main cause of waste incidence was identified. Therefore, the analysis phase was continued with the analysis process using FMEA to determine the priority value of main causes of problems, and then it was continued toward the phase of improvement i.e. 
the phase to determine the improvement of known waste causes. To establish the best alternative that can be taken, an FMEA analysis was performed. Each alternative was assessed for its performance and cost and to determine the value that the company gets with each alternative application. The selected alternative with the largest value was proposed to the company.

Sutrisno and Lee (2011) reveals that correct evaluation of RPN is important in FMEA stage as it is the basis for resource allocation to reduce the causes of reliability problems to address the shortcomings of RPN estimation method based on Military Standard 1629A. After the best alternative was determined, a recalculation of baseline measurement was performed, including DPMO and sigma value. This is to prove that the selected improvement alternative can really benefit the company. The last phase is the control phase, and this phase is a phase to provide an alternative control mechanism to the alternative course of improvement. Figure 1 shows the research framework of DMAIC method. According to Pyzdex (2003), DMAIC is a methodology used to improve and control processes as well as improvements in every stage of the production process. Based on Gijo et al. (2014), DMAIC is an integrated tool and system that makes the sixsigma method different from other problem solving techniques.

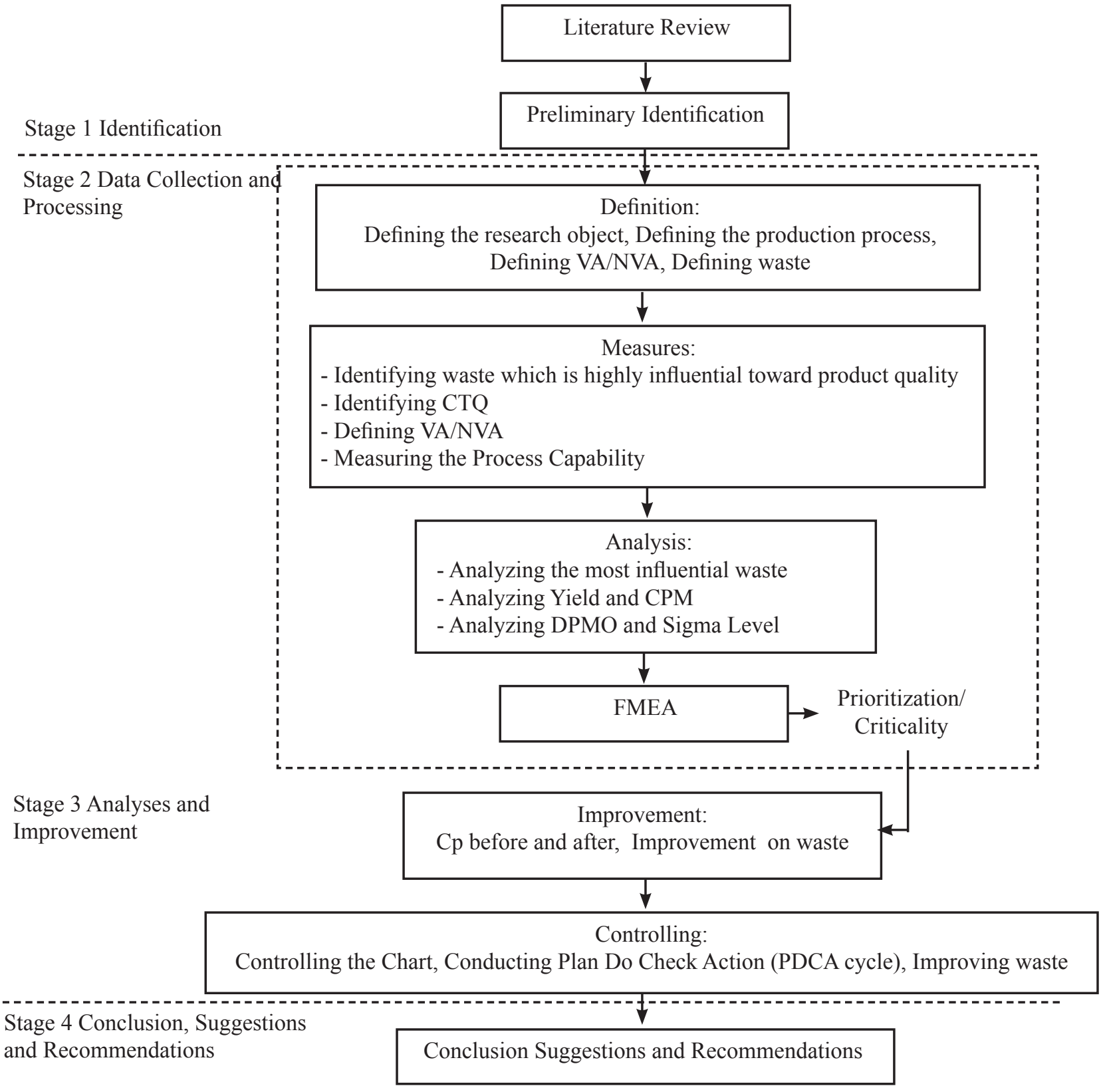

Figure 1. Research framework 


\section{RESULT}

\section{Analysis on Waste/Loss Level using the 7 Waste approach and Value Added (VA)/Non Value Added Activities (NVA)}

1) Defining Stage: The biscuit production process and determination of VA/NVA activities

PT. XYZ manufactures various biscuits in its five production lines. The production process of each line is run fulltime based on the needs of the process that can be fulfilled by each machine. Asmah (2011) conducted a research on biscuit production design in Ghana Africa and says that the biscuit production process covers the stages of raw material preparation, mixing or mixing, forming or molding, baking or by oven, cooling and packing. Each process has a certain design and layout in order to obtain quality, process capability and good capacity in order to meet the needs of consumers.

Figure 2 describes the production process of PT. XYZ starting from the raw material preparation, mixing, forming, baking, creaming or sandwich, cooling and packing where each process had CTQ or critical to quality according to the standard of each process.

Analysis on the mapping process of the whole series of biscuit production is illustrated by some activities that are classified as non value-added activities and some value-added activities (Tables 1 and 2). Based on the time measure of the value-added and non-value added activities, the value of Process Cycle Efficiency (PCE) of $47.29 \%$ was obtained. The value of PCE is the result of division between Value Added Time and Total Cycle Time.
A company can be considered Lean if the ratio of value-to-waste ratio has reached a minimum of $30 \%$; therefore, if the company is not lean, it can be called Un-Lean and can be categorized as a traditional company (George, 2002). Because the value of PCE is above $30 \%$, the production process at $\mathrm{PT}$. $\mathrm{XYZ}$ is classified as a company that has applied Lean process (Gazperzs, 2011).

2) Measure Stage: Waste Identification

Based on the observation on the biscuit production process in PT.XYZ, several waste resources have been identified i.e. non-standard process, product drops, error metal detector detection, broken, oval, overweight or small products, imperfect shape, non-standard water content, malfunction process, and engine breakdown.

According to Liker (2004), Toyota identifies seven types of waste, and they include 1. Overproduction, 2.waiting time, 3. Unnecessary transportation, 4. Excessive or erroneous processing, 5. Excessive inventory, 6. Unnecessary movement, and 7. Defective product. Liker also adds the eighth waste that is the unused creativity of employees. Table 3 shows the number of waste occurrences during the period of January 2015 March 2015.

Table 3 illustrates that the highest level of waste is in the Transportation category of $47.31 \%$, followed by the Product Defect waste of $19.34 \%$ and Inappropriate Processing of $18.16 \%$ in the form of Pareto diagram as seen in Figure 3 seen where Transportation had the greatest waste.

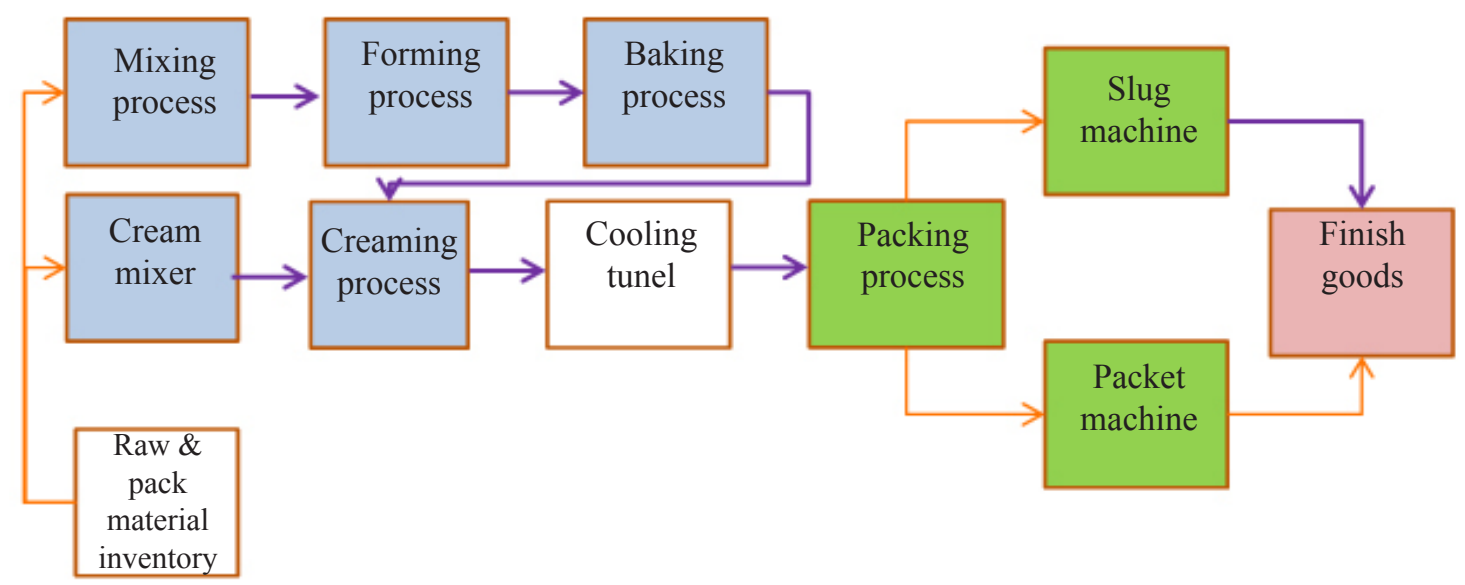

Figure 2. Biscuit production process 
Table 1. The value added process in the biscuit manufacturing

\begin{tabular}{lc}
\hline \multicolumn{1}{c}{ Activity } & Time (Minute) \\
\hline Preparation of flour material & 4.45 \\
Preparation of oil material & 2.05 \\
Weighing of other materials & 11 \\
Mixing Process & 20.32 \\
Forming Process & 1.43 \\
Baking Process & 3.3 \\
Cooling Process 1 & 5.58 \\
Sandwich Process & 7.08 \\
Cream Mixing Process & 5.8 \\
Cooling Process 2 & 4.28 \\
Packing Process & 6.49 \\
Cartooning Process & 4.5 \\
\multicolumn{1}{c}{ Total } & 76.28 \\
\hline
\end{tabular}

Table 2. Non value added process in the biscuit manufacturing

\begin{tabular}{lc}
\hline \multicolumn{1}{c}{ Activity } & Time (Minute) \\
\hline Lay Time- Dough & 45.0 \\
QC Product Check & 40.0 \\
Total & 85.0 \\
\hline
\end{tabular}

Table 3. Types and Number of waste occurrences in Line 5 at PT. XYZ

\begin{tabular}{lcc}
\hline \multicolumn{1}{c}{ Category of 7 Wastes } & Total $(\mathrm{Kg})$ & $\%$ \\
\hline Overproduction & 58.4 & 0.02 \\
Transportation & 129596.33 & 47.31 \\
Waiting & 24794.99 & 9.05 \\
Inappropriate Processing & 49746.90 & 18.16 \\
Unnecessary Inventory & 8765.58 & 3.20 \\
Unnecessary Motion & 8016.87 & 2.93 \\
Defects & 52974.59 & 19.34 \\
\hline
\end{tabular}

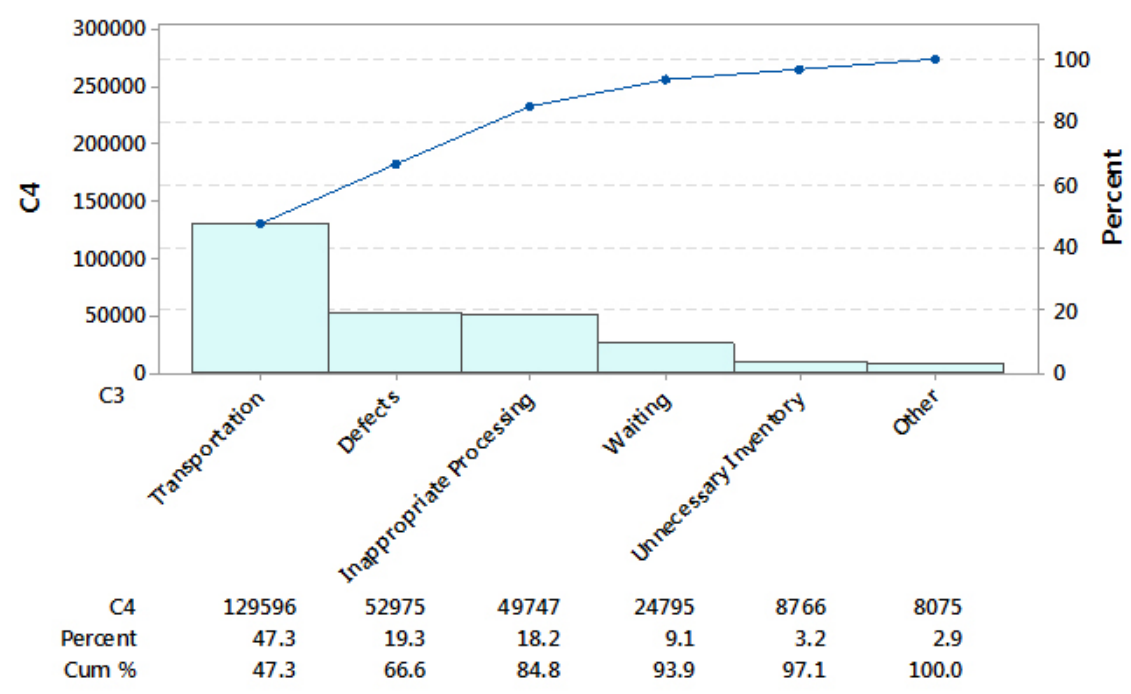

Figure 3. Pareto Diagrams of Dissipation Types

3). Analysis Stage: Determination of Critical to Quality (CTQ) and Cpm value

Critical to Quality or CTQ is a standardized or critical measure at every stage of production processes in order to produce quality products that meet the consumers' expectation in accordance with the capabilities of process technology available. In relation to the measurement of this CTQ, Gazperzs (2011) suggests that the characteristics of quality that will satisfy customers should be identified first. Following this, the quality characteristics considered as critical and that should be controlled are classified, and each quality characteristic that has been classified should be determined to see whether it can be controlled through material control, machines, work processes, and others. At CTQ, a maximum tolerance limit (USL= Upper Specification Limit) and a minimum tolerance limit (LSL: Lower Specification Limit) were set up. The values of USL and LSL will determine the process variation for each classified quality characteristic, and they can also be used as signposts for product and process developments. The range of USL and LSL values is determined by the value of $\pm \mathrm{n}$ sigma, and the Six-sigma approach (DMAIC method) is used as a reference in order to decrease waste or loss (Hasan, 2013). Based on the experience of its production process, PT. XYZ has established CTQ at each stage of the production process as presented in Table 4 . 
Table 4. CTQ of Biscuit Production Process in Line 5 of PT. XYZ

\begin{tabular}{lccccc}
\hline \multicolumn{1}{c}{ Process Stage } & Critical to Quality (CTQ) & Measurement Unit & Batas Bawah & Median Value & Batas Atas \\
\hline Preparation of raw & Process 1 & $\mathrm{Kg}$ & 5.48 & 5.54 & 5.60 \\
materials & Process 2 & $\mathrm{Kg}$ & 9.89 & 9.99 & 10.09 \\
& Process 3 & $\mathrm{Kg}$ & 0.124 & 0.126 & 0.127 \\
& Process 4 & $\mathrm{Kg}$ & 11.89 & 12.01 & 12.13 \\
Mixing & Process 5 & "C & 28 & 30 & 32 \\
& Process 6 & $\mathrm{Kg}$ & 890.01 & 899.3 & 908.29 \\
& Process 7 & $\mathrm{Kg}$ & 393.5 & 379.5 & 401.5 \\
& Process 8 & $\mathrm{Kg}$ & 58.9 & 59.5 & 60.09 \\
& Process 9 & $\mathrm{Kg}$ & 96.72 & 97.7 & 98.67 \\
Forming & Process 10 & $\mathrm{Gr}$ & 18.5 & 19.9 & 21.3 \\
& Process 11 & $\mathrm{Gr}$ & 16.75 & 17.5 & 18.25 \\
Oven & Process 12 & $\mathrm{Mm}$ & 46 & 47.5 & 49 \\
& Process 13 & $\mathrm{Mm}$ & 41.5 & 42.5 & 43.5 \\
& Process 14 & \% & 1.7 & 2.4 & 3.2 \\
& Process 15 & $\mathrm{pH}$ & 8 & 8.5 & 9 \\
Sandwich & Process 16 & $\mathrm{Gr}$ & 28.5 & 29.4 & 30.3 \\
& Process 17 & $\mathrm{Mm}$ & 36 & 36.3 & 37.2 \\
Packing & Process 18 & Gr & 130.84 & 137 & 143.16 \\
& Process 19 & Gr & 26.75 & 29.4 & 32.05 \\
\hline
\end{tabular}

\section{Evaluation on Capability Value}

According to Anuragiri and Babu (2013), the implementation of six-sigma aims to improve customer satisfaction through enhanced process capability. This is performed by focusing on the fulfillment of Critical to Quality (CTQ) and by implementing corrective actions to continuously reduce the variability of each process stage. Measurement of CTQ fulfillment was conducted using Cpm parameter and calculated using the following formula.

$$
C_{p m}=\frac{C_{p}}{\sqrt{1+\frac{(\overline{\bar{x}}-T)^{2}}{\sigma_{x}^{2}}}}
$$

Pyzdex (2003) states that Cpm describes the capability of a process stage toward CTQ. Based on the observation of the ongoing production process, the results of the calculation of $\mathrm{Cpm}$ at the stage of the forming process are presented in Figure 3.

Figure 3 shows the result of the data processing of weighing of $\mathrm{Cpm}$ forming process of 1.17 , indicating that the process capability is reasonably good in which the value of $\mathrm{Cpm}$ is greater than 1 . Table 5 presents the process capability of the Cpm for all stages of the processes using Minitab 17. Each stage was performed using CTQ per stage, and the Cpm was measured.

PT. XYZ has several production process stages, each of which will result in measurable process performance based on CTQ conformance to the existing production process data. Y rt at PT. XYZ is based on Quality Yield, Availability Yield, and Performance Yield. This calculation process used the model developed by Harry (2000) and Breyfogle III (2003).

$$
Y_{R T}=\prod_{i=1}^{n} Y_{i}
$$

Yrt : Total Rolled Throughput Yield

n : number of process stages

Yi : Process stages

The existing Yield of each stage of the processes was calculated in accordance with the above formula and Yrt value was obtained. From the sigma value calculation data, the values of Yield Quality of 70.39\%, Yield Availability of $90.12 \%$ and Yield Performance of $88.75 \%$ were obtained so that the total Rolled Thoughput Yield was $56.30 \%$. Table 6 shows the result of the calculation of Yrt value. 


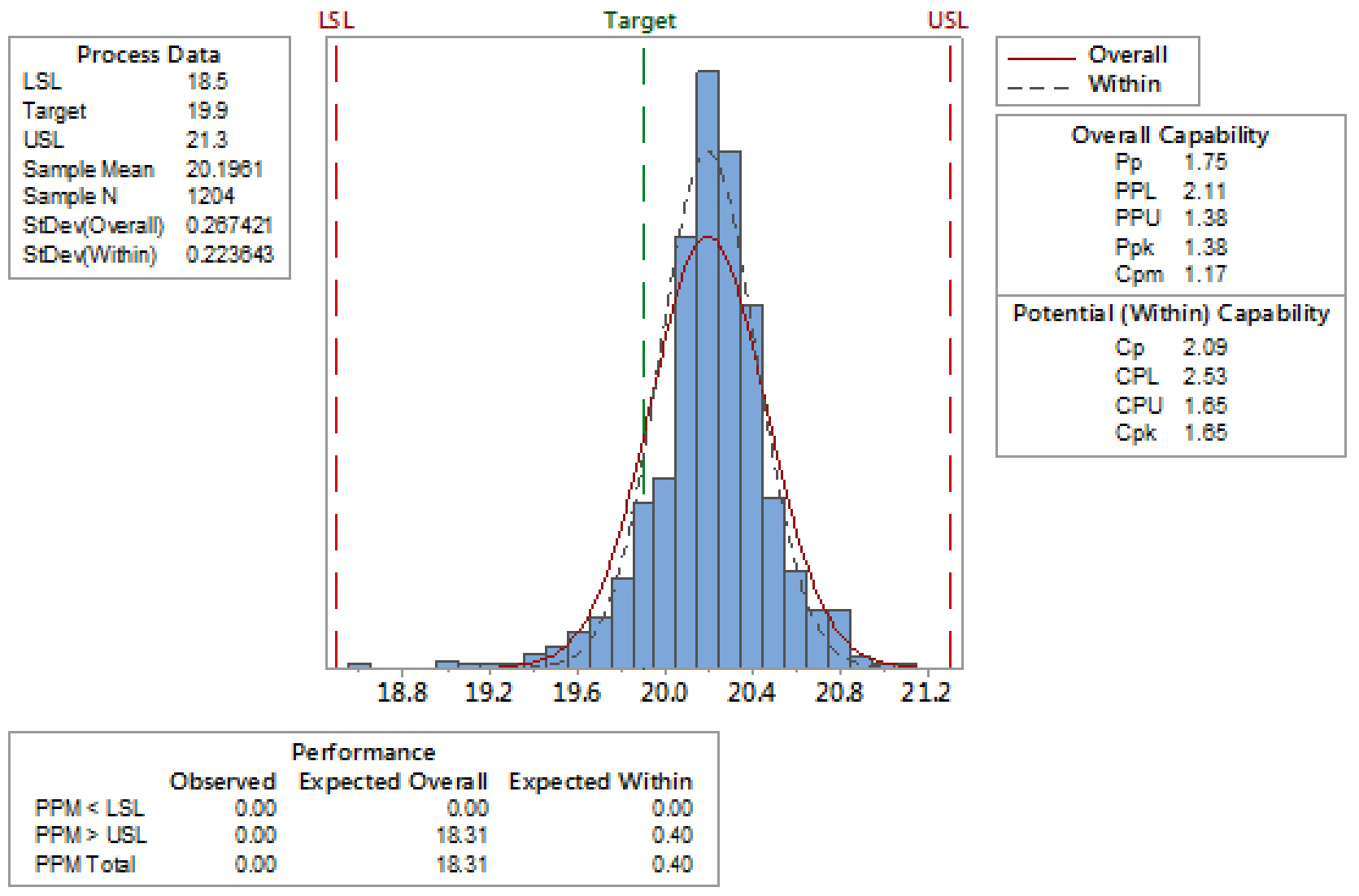

Figure 3. Weight forming graph of $\mathrm{Cpm}$

Table 5. the results of the measurements of Cpm capability at all stages of process

\begin{tabular}{lcccccc}
\hline \multicolumn{1}{c}{ Process Stage } & Critical to Quality (CTQ) & Unit of Measure & LSL & Target & USL & CPM \\
& & & & & & \\
\hline Preparation of raw & Process 1 & $\mathrm{Kg}$ & 5.48 & 5.54 & 5.6 & 6 \\
materials & Process 2 & $\mathrm{Kg}$ & 9.89 & 9.99 & 10.09 & 5.62 \\
& Process 3 & $\mathrm{Kg}$ & 0.124 & 0.126 & 0.127 & 16.49 \\
& Process 4 & $\mathrm{Kg}$ & 11.89 & 12.01 & 12.13 & 49.4 \\
Mixing & Process 5 & Derajat Celcius & 28 & 30 & 32 & 0.75 \\
& Process 6 & $\mathrm{Kg}$ & 890.01 & 899.3 & 908.29 & 2.28 \\
& Process 7 & $\mathrm{Kg}$ & 393.5 & 379.5 & 401.5 & 0.32 \\
& Process 8 & $\mathrm{Kg}$ & 58.9 & 59.5 & 60.09 & 13.01 \\
Forming & Process 9 & $\mathrm{Kg}$ & 96.72 & 97.7 & 98.67 & 28.5 \\
& Process 10 & $\mathrm{Gr}$ & 18.5 & 19.9 & 21.3 & 1.17 \\
Oven & Process 11 & $\mathrm{Gr}$ & 16.75 & 17.5 & 18.25 & 1 \\
& Process 12 & $\mathrm{Mm}$ & 46 & 47.5 & 49 & 0.6 \\
& Process 13 & $\mathrm{Mm}$ & 41.5 & 42.5 & 43.5 & 0.47 \\
& Process 14 & \% & 1.7 & 2.4 & 3.2 & 1.08 \\
Sandwich & Process 15 & & 8 & 8.5 & 9 & 0.88 \\
& Process 16 & $\mathrm{Gr}$ & 28.5 & 29.4 & 30.3 & 0.96 \\
Packing & Process 17 & $\mathrm{Mm}$ & 36 & 36.3 & 37.2 & 3.88 \\
& Process 18 & $\mathrm{Gr}$ & 130.84 & 137 & 143.16 & 1.09 \\
& Process 19 & $\mathrm{Gr}$ & 26.75 & 29.4 & 32.046 & 1.52 \\
\hline \multirow{5}{*}{} & & & & & &
\end{tabular}


Table 6. Yrt calculation of process stages

\begin{tabular}{lcccc}
\hline \multicolumn{1}{c}{ Stages } & Yield (Quality) & Yield (Availability) & Yield (Performance) & Yield Total \\
\hline Ingredient Delivery & $84.12 \%$ & $100.00 \%$ & & \\
Mixing & $100.00 \%$ & $97.11 \%$ & & \\
Forming & $100.00 \%$ & $99.44 \%$ & $88.75 \%$ & \\
Baking & $83.83 \%$ & $97.63 \%$ & & \\
Sandwich & $99.91 \%$ & $98.20 \%$ & & \\
Packing & $99.91 \%$ & $97.35 \%$ & & \\
\hline \multicolumn{1}{c}{ Total } & $70.39 \%$ & $90.12 \%$ & $88.75 \%$ & \\
\hline
\end{tabular}

The values of DPU (Defect per Unit), DPMO (Defects per Million Opportunities) and sigma value were then calculated. According Jirasukprasert et al. (2014), after the number of defects was identified the sigma value of the manufacturing process was then calculated. The calculation results are presented in Table 7.

The research obtained the values of DPU of 0.5744 , DPMO of 29632.6, and sigma of 3.39. This shows that the biscuit production of Line 5 of PT. XYZ has a production capability with a failure of 29.632 .6 every $1,000,000$ productions, or equivalent to $2.96 \%$ loss, and this indicates the production process in Line- 5 still has a high failure rate.

\section{Improvement Stages (Determination of FMEA)}

In regards to improvement, a number of improvement steps at each stage of the existing processes from the preparation of materials, mixing, forming, baking, sandwich and packing were established and then tabulation on FMEA analysis was carried out. The FMEA method is also used to determine the failure of the process and to analyze and improve the production quality (Puspitasari and Martanto, 2014). The results of FMEA analysis on the production process stages of PT XYZ are presented in Table 8.

The result of FMEA in Table 8 explains that each stage of the process has potential damage, in accordance with the discussion with the company and brain storming conducted with the manufacturing team of PT. XYZ. Figures in the stages of the process are 500-1000 for the raw material preparation, $180-360$ for mixing, 500-800 for forming stage, 240-1000 for process, 800-1000 for conveying process stages, 1000 for sandwich and 600-1000 for packing. This shows that every process conducted at PT. XYZ has potential damage that will result in waste and potential problems with product quality. Similarly, from the results of the measure stage, several stages of the processes that require increased process capability including improving the Guerin system or raw material weighing through maintenance plan system, load cell repair, and several other processes were obtained.

\section{Managerial Implication}

Based on the FMEA obtained from this study, the management needs to prioritize and focus on several problems at each stage of the production processes from raw material preparation, mixing process, forming process, oven process, sandwich process to packing process. According to Gijo et al. (2013), six-sigma DMAIC methodology has been successful in improving process conditions with only simple solutions, without investment or cost impacts for the company. The result of determination of improvement priority through the FMEA process needs to be followed up in the form of project implementation, either through a six-sigma project or lean project, conducted the by internal company, through Yellow Belt, Green Belt, Black Belt or a small group activity (SGA) project.

Priority of improvement should be given to the process that has the greatest RPN or Risk Priority Number impact of $800-1000$ so that it will get a significant improvement rate. Table 9 presents some of the recommendations from the research results obtained from the FMEA and priority of the improvements made. 
Table 7. Calculations of Yrt, DPU, DPMO and Sigma Level

\begin{tabular}{|c|c|c|c|c|c|}
\hline Tahapan & Yield Total & Opportunity & Unit DPU & Unit DPMO & Sigma Level \\
\hline Ingredient Delivery & & 12 & & & \\
\hline Mixing & & 1 & & & \\
\hline Forming & & 1 & & & \\
\hline Baking & & 1 & & & \\
\hline Sandwich & & 1 & & & \\
\hline Packing & & 3 & & & \\
\hline Total & $56.30 \%$ & 19 & 0.5744 & 29632.607 & 3.39 \\
\hline
\end{tabular}

Table 8. Determination of Failure Mode and Effect Analysis (FMEA)

\begin{tabular}{|c|c|c|c|c|c|c|c|c|c|}
\hline Processes & $\begin{array}{l}\text { Steps/ } \\
\text { Inputs }\end{array}$ & $\begin{array}{c}\text { Damage } \\
\text { Potentials }\end{array}$ & $\begin{array}{l}\text { Damage } \\
\text { Effects }\end{array}$ & SEV & $\begin{array}{c}\text { Potential } \\
\text { Causes }\end{array}$ & $\mathrm{OCC}$ & $\begin{array}{l}\text { Current } \\
\text { control }\end{array}$ & DET & RPN \\
\hline \multirow{4}{*}{$\begin{array}{l}\text { Guerin } \\
\text { System/ } \\
\text { Material } \\
\text { preparation }\end{array}$} & $\begin{array}{l}\text { Material } \\
\text { weighing }\end{array}$ & $\begin{array}{l}\text { Blocking Sugar } \\
\text { at Hopper }\end{array}$ & Line STOP & 10 & $\begin{array}{l}\text { Broken } \mathrm{AC} / \\
\text { damaged } \\
\text { Filter }\end{array}$ & 10 & $\begin{array}{l}\text { No } \\
\text { monitoring }\end{array}$ & 10 & 1000 \\
\hline & & $\begin{array}{l}\text { No electricity } \\
\text { power }\end{array}$ & $\begin{array}{l}\text { Damaged } \\
\text { dough }\end{array}$ & 10 & $\begin{array}{l}\text { Main } \\
\text { Distributor } \\
\text { Panel Trip }\end{array}$ & 6 & $\begin{array}{l}\text { No } \\
\text { monitoring }\end{array}$ & 10 & 600 \\
\hline & & $\begin{array}{l}\text { Blank system/ } \\
\text { disappeared }\end{array}$ & DT \& waste & 10 & Electrical trip & 5 & $\begin{array}{l}\text { Nonexistent } \\
\text { Maintenance } \\
\text { Plan Program }\end{array}$ & 10 & 500 \\
\hline & & $\begin{array}{l}\text { Load cell (how } \\
\text { balance works) }\end{array}$ & $\begin{array}{l}\text { Unstable } \\
\text { dough }\end{array}$ & 10 & $\begin{array}{l}\text { no training } \\
\text { on problem } \\
\text { solving }\end{array}$ & 10 & Undetectable & 10 & 1000 \\
\hline \multirow[t]{4}{*}{$\begin{array}{l}\text { Mixing } \\
\text { Process }\end{array}$} & Mixing & $\begin{array}{l}\text { Different } \\
\text { usage of water } \\
\text { between shifts }\end{array}$ & $\begin{array}{l}\text { Unstable } \\
\text { dough and } \\
\text { waste }\end{array}$ & 6 & $\begin{array}{l}\text { Differences } \\
\text { in methods } \\
\text { by operators }\end{array}$ & 10 & $\begin{array}{l}\text { Controlling } \\
\text { only after } \\
\text { mixing is } \\
\text { finished }\end{array}$ & 6 & 360 \\
\hline & & $\begin{array}{l}\text { Frequently } \\
\text { error censor }\end{array}$ & $\begin{array}{l}\text { Down time } \\
\text { and safety } \\
\text { issue }\end{array}$ & 6 & $\begin{array}{l}\text { Unstable } \\
\text { socket pad }\end{array}$ & 10 & $\begin{array}{l}\text { Alarm system } \\
\text { of mixer is on }\end{array}$ & 5 & 300 \\
\hline & & $\begin{array}{l}\text { Mechanical } \\
\text { Seal leaking } \\
\text { Mixer }\end{array}$ & $\begin{array}{l}\text { Dirty and } \\
\text { wasteful }\end{array}$ & 6 & Broken Seal & 10 & $\begin{array}{l}\text { Control } \\
\text { visual }\end{array}$ & 5 & 300 \\
\hline & & $\begin{array}{l}\text { Differences in } \\
\text { resting time }\end{array}$ & $\begin{array}{l}\text { Different } \\
\text { dough } \\
\text { character and } \\
\text { unstable and } \\
\text { wasteful }\end{array}$ & 6 & $\begin{array}{l}\text { Considerably } \\
\text { wide range }\end{array}$ & 10 & SOP & 3 & 180 \\
\hline \multirow[t]{3}{*}{$\begin{array}{l}\text { Forming } \\
\text { Process }\end{array}$} & Forming & $\begin{array}{l}\text { Greper/ Tailing } \\
\text { in the process }\end{array}$ & Product jam & 10 & $\begin{array}{l}\text { Error molder } \\
\text { censor }\end{array}$ & 10 & $\begin{array}{l}\text { manual } \\
\text { process } \\
\text { control }\end{array}$ & 8 & 800 \\
\hline & & Product Tailing & Product jam & 10 & $\begin{array}{l}\text { Uneven } \\
\text { surface of } \\
\text { knives }\end{array}$ & 10 & $\begin{array}{l}\text { Checklist of } \\
\text { forming }\end{array}$ & 5 & 500 \\
\hline & & Product Tailing & $\begin{array}{l}\text { Product Jam/ } \\
\text { Minor stop }\end{array}$ & 10 & $\begin{array}{l}\text { Loose molder } \\
\text { Teflon }\end{array}$ & 10 & Visual control & 8 & 800 \\
\hline $\begin{array}{l}\text { Oven } \\
\text { Process }\end{array}$ & $\begin{array}{l}\text { Baking } \\
\text { Process }\end{array}$ & $\begin{array}{l}\text { Uneven } \\
\text { thickness of } \\
\text { biscuit }\end{array}$ & $\begin{array}{l}\text { Unstable } \\
\text { thickness of } \\
\text { biscuits }\end{array}$ & 10 & $\begin{array}{l}\text { Uneven } \\
\text { weight } \\
\text { among rows }\end{array}$ & 10 & $\begin{array}{l}\text { Check list } \\
\text { of intense } \\
\text { monitoring }\end{array}$ & 5 & 500 \\
\hline
\end{tabular}


Table 8. Determination of Failure Mode and Effect Analysis (FMEA) (continu)

\begin{tabular}{|c|c|c|c|c|c|c|c|c|c|}
\hline Processes & $\begin{array}{l}\text { Steps/ } \\
\text { Inputs }\end{array}$ & $\begin{array}{c}\text { Damage } \\
\text { Potentials }\end{array}$ & $\begin{array}{l}\text { Damage } \\
\text { Effects }\end{array}$ & SEV & $\begin{array}{c}\text { Potential } \\
\text { Causes }\end{array}$ & $\mathrm{OCC}$ & $\begin{array}{l}\text { Current } \\
\text { control }\end{array}$ & DET & RPN \\
\hline & & $\begin{array}{l}\text { Wiremesh } \\
\text { vibration }\end{array}$ & $\begin{array}{l}\text { Product } \\
\text { gandeng, } \\
\text { waste }\end{array}$ & 6 & $\begin{array}{l}\text { Unstable air } \\
\text { pressure }\end{array}$ & 4 & $\begin{array}{l}\text { No indicator } \\
\text { of pressure }\end{array}$ & 10 & 240 \\
\hline & & $\begin{array}{l}\text { Wiremesh } \\
\text { vibration }\end{array}$ & $\begin{array}{l}\text { Product } \\
\text { gandeng, } \\
\text { minor stop }\end{array}$ & 10 & $\begin{array}{l}\text { Bended mesh } \\
\text { wire }\end{array}$ & 10 & No control & 10 & 1000 \\
\hline & & Product Jam & $\begin{array}{l}\text { Waste/minor } \\
\text { Stop }\end{array}$ & 10 & $\begin{array}{l}\text { One side of } \\
\text { Wire mesh is } \\
\text { loose }\end{array}$ & 10 & Visual control & 7 & 700 \\
\hline \multirow[t]{3}{*}{$\begin{array}{l}\text { Conveying } \\
\text { process }\end{array}$} & Conveyor & $\begin{array}{l}\text { Product is } \\
\text { jammed at the } \\
\text { channeling } \\
\text { conveyor }\end{array}$ & $\begin{array}{l}\text { Waste/minor } \\
\text { stop }\end{array}$ & 10 & $\begin{array}{l}\text { Biscuits were } \\
\text { not censored } \\
\text { due to their } \\
\text { dirtiness }\end{array}$ & 10 & $\begin{array}{l}\text { no control/ } \\
\text { monitor }\end{array}$ & 10 & 1000 \\
\hline & & $\begin{array}{l}\text { Bended cake } \\
\text { base }\end{array}$ & Line Stop & 10 & $\begin{array}{l}\text { Scrap } \\
\text { was taken } \\
\text { accidentally } \\
\text { by Teflon }\end{array}$ & 10 & only Visual & 8 & 800 \\
\hline & & $\begin{array}{l}\text { Product is } \\
\text { jammed at the } \\
\text { channeling } \\
\text { packing }\end{array}$ & $\begin{array}{l}\text { Waste/Minor } \\
\text { Stop }\end{array}$ & 10 & $\begin{array}{l}\text { No sorting } \\
\text { activity }\end{array}$ & 10 & no control & 10 & 1000 \\
\hline \multirow[t]{2}{*}{$\begin{array}{l}\text { Sandwich } \\
\text { process }\end{array}$} & Sandwich & $\begin{array}{l}\text { Thin or thick } \\
\text { biscuits }\end{array}$ & $\begin{array}{l}\text { packing } \\
\text { machine often } \\
\text { starts or stops }\end{array}$ & 10 & $\begin{array}{l}\text { Cream } \\
\text { texture is } \\
\text { different } \\
\text { since the } \\
\text { icing weight } \\
\text { is different }\end{array}$ & 10 & $\begin{array}{l}\text { no automatic, } \\
\text { manual check }\end{array}$ & 10 & 1000 \\
\hline & $\begin{array}{l}\text { Mixing } \\
\text { cream }\end{array}$ & $\begin{array}{l}\text { Unstable } \\
\text { Cream }\end{array}$ & $\begin{array}{l}\text { Waste/ thin or } \\
\text { thick }\end{array}$ & 10 & $\begin{array}{l}\text { Inaccurate } \\
\text { balance or } \\
\text { weighing } \\
\text { scale }\end{array}$ & 10 & $\begin{array}{l}\text { Inappropriate } \\
\text { Display }\end{array}$ & 10 & 1000 \\
\hline \multirow[t]{3}{*}{$\begin{array}{l}\text { Packing } \\
\text { Process }\end{array}$} & $\begin{array}{l}\text { Product } \\
\text { packaging }\end{array}$ & $\begin{array}{l}\text { Broken } \\
\text { Products }\end{array}$ & $\begin{array}{l}\text { Dead } \\
\text { machine, } \\
\text { quality } \\
\text { potential }\end{array}$ & 10 & $\begin{array}{l}\text { No sorting } \\
\text { tool of } \\
\text { sandwich } \\
\text { since taken } \\
\text { accidentally } \\
\text { to packing }\end{array}$ & 10 & Visual & 10 & 1000 \\
\hline & & Oval products & $\begin{array}{l}\text { Dead machine } \\
\text { and waste }\end{array}$ & 10 & $\begin{array}{l}\text { Over } \\
\text { Proofing }\end{array}$ & 6 & SOP & 10 & 600 \\
\hline & & Smearing & $\begin{array}{l}\text { More rejected } \\
\text { products }\end{array}$ & 10 & $\begin{array}{l}\text { Warm } \\
\text { Cooling } \\
\text { tunnel }\end{array}$ & 10 & Nonexistent & 10 & 1000 \\
\hline
\end{tabular}

CONCLUSIONS AND RECOMMENDATIONS

\section{Conclusions}

The conclusion of this research is that the production process at PT. XYZ of Line-5 is classified as production process applying the Lean process. The results obtained
VA (Value Added) of 76.28 minutes and NVA (Non Value Added) of 85 minutes in the production process of Line-5 at PT. XYZ with the value of Process Cycle Efficiency (PCE) of $47.29 \%$, indicating that PT. XYZ has implemented Lean System. The two largest values obtained from the identification stage are $47.31 \%$ from transportation and $19.34 \%$ from defect products. 
The Sigma value obtained is 3.39, and Line 5 biscuit production process obtained DPMO of 29632.607, and this sigma value of capability, the biscuit production process at PT.XYZ, is included in the minimum standard of sigma value to produce $25-40 \%$, and chance of getting COPQ or Cost if Poor Quality. However, it can be said that this company is categorized as a good company although Quality Yields need to be improved especially in the process stages of $\mathrm{Cpm}<1$.

\section{Recommendations}

Further research is required for $\mathrm{PT} \mathrm{XYZ}$ in terms of increasing production processes in some other production processes i.e. Line 1, 2, 3 and 4 using this DMAIC methodology. This study needs to be continued in terms of FMEA usage along with the project selection model for improving the production process. The study should be continued with a combination of other methodologies such as TPM approach and other methods of improvement. Similar research also should be conducted in order to provide added value in the fields of food or agriculture with the application of Lean Six-sigma methodology.

\section{REFERENCES}

Ammar A. 2011. Using six sigma tools to measure and improve the performance of a manufacturing supply chain [thesis]. US: Texas Technical university.

Arunagiri P, Babu GA. 2013. Review on reduction of delay in manufacturing process using lean six sigma (LSS) system). International Journal of Scientific and Research Publication 3(2): 693697.

Asmah F. 2011. Setting Up Biscuits Production Company in Ghana. Ghana: Savonia University of Applied Science.

Furterer SL. 2011. Applying lean six sigma to reduce linen loss in an acute care hospital. International Journal of Engineering, Science and Technology 3(2011): 39-55.

Gazpersz V. 2011. Lean Six Sigma for Manufacturing and Service Industries - Waste Elimination and continuous cost reduction. Bogor: Vinchristo Publication.

George ML. 2003. Lean Six Sigma for Service. New York: McGraw-Hill.
Gijo EV, Anthony J, Hernandez J, Scaria J. 2013. Reducing patient waiting time in a pathology department using Six Sigma methodology. Joural Leadership in Health Services 26(4): 253-267.https://doi.org/10.1108/LHS-02-20120004.

Gijo EV, Anthony J, Kumar M, Mc Adam R, Hernandez J. 2014. An application of Six Sigma methodology for improving the first pass yield of a griding process. Journal of Manufacturing Technology 25(1): 125-135. https://doi.org/10.1108/JMTM12-2011-0109.

Hassan MK. 2013. Applying lean six sigma for waste reduction in a manufacturing environment. American Journal of Industrial Engineering 1(2): 28-35.

Harry M, Schroeder R. 2000. Six Sigma: The Breakthrough Management Strategy Revolutionalizing the World's Top Corporations. New York: Currency/Doubleday.

Jirasukprasert P, Garza-Reyes JA, Kumar V, Lim MK. 2014. A Six Sigma and DMAIC application for reduction of defects in a rubber gloves manufacturing process. International Journal of Lean Six Sigma 5(1): 2-21. https://doi. org/10.1108/IJLSS-03-2013-0020.

Kumar D, Kaushish D. 2015. Scrap reduction in a piston manufacturing industry: an analysis using six sigma and DMAIC methodology. The IUP Journal of Operations Management XIV(2): 233-245.

Liker JK. 2004. Toyota Way: 14 Management Principles from the World's Greatest Manufacturer. McGraw-Hill Education: New York, Chicago, San Francisco, Athens, London, Madrid, Mexico City, Milan, New Delhi, Singapore, Sydney, Toronto.

Puspitasari NB, Martanto A. 2014. Penggunaan FMEA dalam mengidentifikasi resiko kegagalan proses produksi sarung ATM (Alat Tenun Mesin) (Studi Kasus PT. Asaputex Jaya Tegal). Jurnal Teknik Industri UNDIP IX(2): 93-98. https://doi. org/10.12777/jati.9.2.93-98.

Pyzdek T. 2003. The Six Sigma Handbook; A Complete Guide For Green Belts, Black Belts, And Managers At All Levels. New York: McGrawHill.

Sutrisno A, Lee TR. 2011. Service reliability assessment using failure mode and effect analysis (FMEA): survey and opportunity roadmap. International 
P-ISSN: 2407-5434 E-ISSN: 2407-7321

Accredited by Ministry of RTHE Number 32a/E/KPT/2017

Journal of Engineering, Science and Technology. 3(7): 25-38.

Stamatis DH. 1995. Failure Mode and Effect Analysis - FMEA from Theory to Execution. New York: ASQC Press.

Womack JP, Jones DT, Roos D. 1990. The Machine

That Changed the World - The Story of Lean
Available online at http://journal.ipb.ac.id/index.php/ijbe

DOI number: 10.17358/IJBE.3.2.77

Production Toyota's Secret Weapon in the Global Car Wars That Is Revolutionizing World Industry. US: Free Press.

Zaqi A, Suseno. 2015. Peningkatan produktivitas perusahaan dengan metode Six Sigma, Lean dan Kaizen. Jurnal Teknik Industri X( 2): 103-116. 